\title{
Coal Geometry Modeling and Resources Estimation in Darmo and Surrounding Area, Muara Enim, South Sumatra
}

\author{
Prayoga Kurniawan \\ Undergraduate Student Program, Department of Geological Engineering, Faculty of Engineering, \\ Universitas Gadjah Mada, Yogyakarta, Indonesia \\ *Corresponding author: prayogak707@gmail.com
}

Article received: 4 December 2020, revised:15 May 2021 accepted: 15 June 2021

DOI: $10.51835 /$ ijeg.2021.1.1.344

\begin{abstract}
This research is located in Darmo, Muara Enim, South Sumatra, while in geological spatial it is located in the Muaraenim Anticlinorium zone. The purpose of this study is to build coal geometry model and calculating coal resources estimation in the study area. The methods applied in this study include field observations, laboratory analysis and studio analysis. Coal geometry modeling is doing by krigging method, as well as the calculation of coal resources using the circular method. The results obtained from this study are in the form of stratigraphic sequence of the youngest namely the Kasai Formation and the Muaraenim Formation. Geometry of coal seams in the study area has a thickness that is quite varied from 0.5 meters - 12.8 meters, in general is continuous, has the characteristics of the roof and floor in the form of sandy coal and muddy coal and interburden in the form of sandstone and claystone. The form of coal seams in the study area is included in the classification of horseback, fault and fold. Estimated coal resources in the study area consist of inferred resources $74677959 \mathrm{~m} 3$ or equivalent to 104549142 tons, indicated resources $69043012 \mathrm{~m} 3$ or 96660216 tons and measured resources $68041837 \mathrm{~m} 3$ or 95258571 tons which is a calculation of estimated coal resources from seam A, seam B, seam C and seamless C and seam D.
\end{abstract}

Keywords: coal, estimation, resources, krigging, circular method

\section{INTRODUCTION}

The Muaraenim Formation is one of the coal-bearing formations in the South Sumatra Basin which is the main target in exploration for coal resources. Based on these conditions, it is necessary to have knowledge and research on coal, especially in geometry and estimation of coal resources in the Muaraenim Formation. The geometry of the coal seam has an important meaning in coal exploration activities, not only to base coal resources calculations, but also to guide the preparation of advanced exploration plans.

The geometric factors that will be observed in this study are depth, thickness of continuity, characteristics of coal, roof, floor, and interburden as well as the shape of the coal seam. Meanwhile, coal resources include inferred, indicated and measured resources. The geometry of coal varies in a basin, in a formation, and even be different in the same layer (Prasongko, 2000). That is influenced by syn depositional geological controls and post depositional geological controls that vary in each location so that a detailed study of the geometry of the coal seam is necessary. Syn depositional geological controls are depositional environment, geological structural processes, different facies, deposition speed, and the amount of supply of coal-forming organic materials. While post depositional geological controls are geological structures, fluvialtic processes, and volcanism. 
The syn depositional and post irregularity of the coal seams that exist in the depositional geological control will affect the research area cannot be separated from the geometry of coal which includes depth, sedimentation process of the Muaraenim thickness, continuity, characteristics of coal, Formation and the influence of the research roof, floor, interburden and the shape of the location which is located in the Anticlinorium coal seam in the Muaraenim Formation. The Muaraenim (Barber, et al., 2005) (Figure 1).

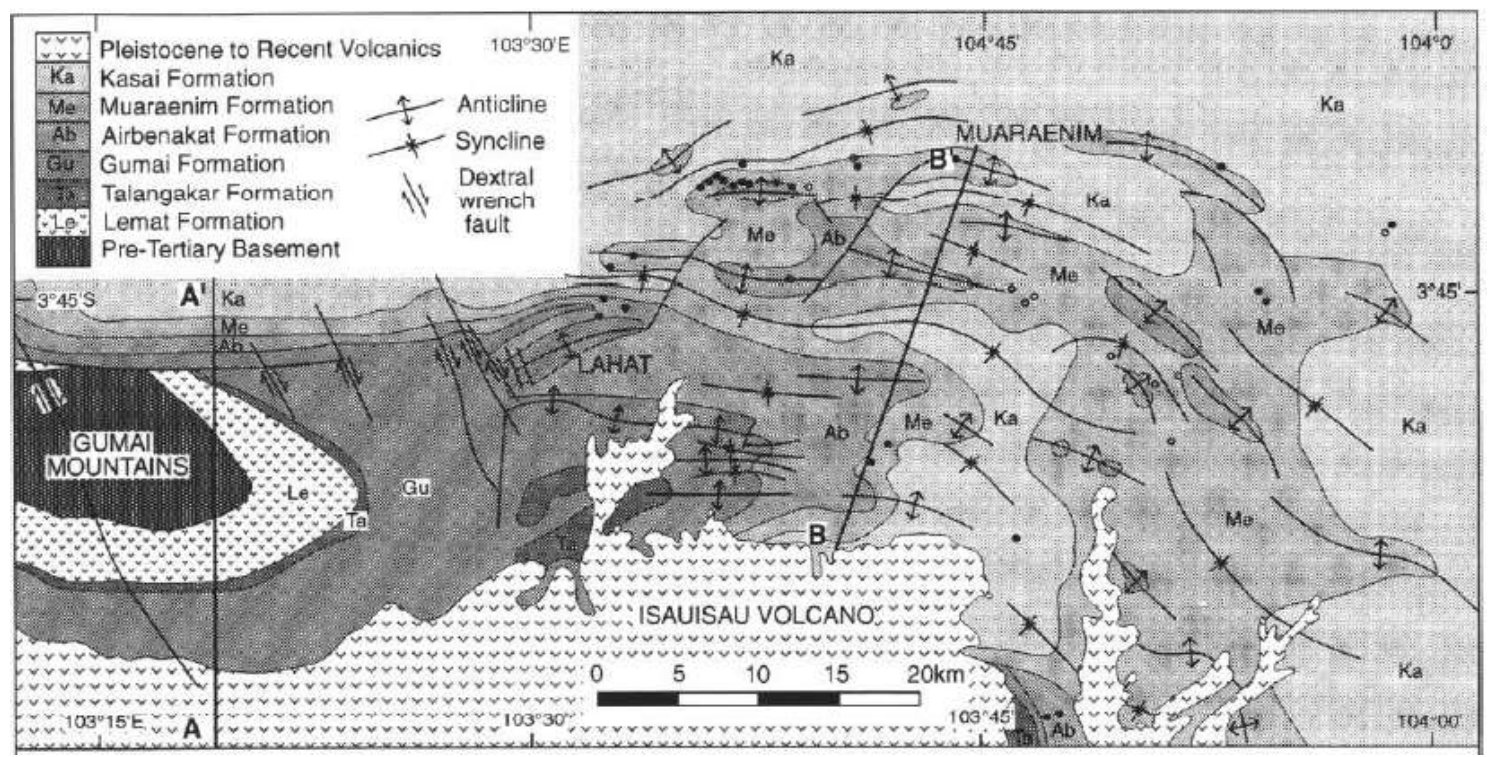

Figure 1. Research location is located in Anticlinorium Muaraenim Zone (Barber, et al., 2005).

The irregular nature of the coal seam is of particular concern in conducting research on the geometry model of the coal seam and in calculating the estimated coal resources. Resources are the amount or quantity of mining materials found on the surface or below the surface which are calculated using a certain method in a series of studies. Estimation of coal resources can be interpreted as an estimate of the potential size of coal in the research area. Based on the density of data information points and the level of complexity of geological control in an area, coal resources are divided into inferred, indicated and measured (SNI, 1998).

\section{METHODOLOGY}

The research method used in this research includes field observations such as measurement of collar data, description of drill samples, and sampling. Laboratory analysis to obtain coal quality (proximate and ultimate) values and studio analysis to model geological conditions, coal geometry and calculate coal resources (Figure 2).

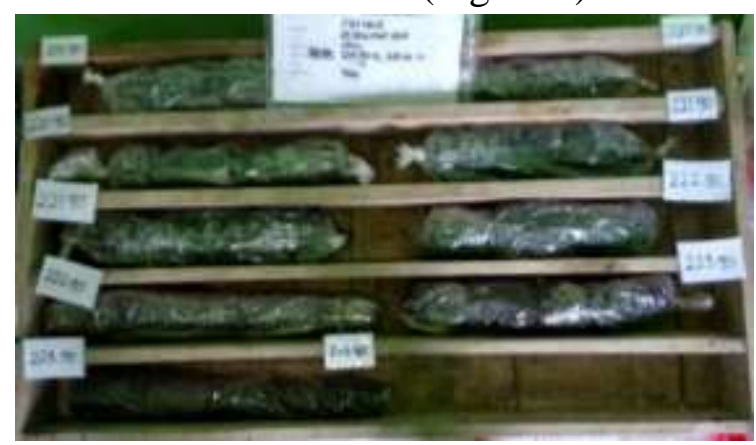

Figure 2. Coal sample to do laboratory aenalysis.

Particular concern in this research is how to model coal geometry and calculate coal resources. In this study, coal geometric modeling was carried out based on the krigging method and coal resource 
calculations were carried out using the circular method. Krigging is a geostatistical method that can be used to interpret the magnitude of the value at an unsampled location using data from a sampled location in the surronding area by considering the spatial correlation in the data (Cressendo \& Gusman, 2020). The use of the krigging method is carried out to interpret elevation data, thickness, distance and the influence of the data from the research object. The way this method works is by using mathematical equations which are carried out using the omnidirectional semi variogram parameter to determine the statistical value and variation of the data held (Bryanco, et al., 2018). In this study, the method of calculating coal resources used is the circular method (USGS, 1983).

The circular method is considered more appropriate and more accurate in calculating coal resources because this method illustrates the varying depth and thickness of coal seams so that they are closer to the actual situation. This method calculates resources using circular polygons at a certain distance from the data information points and also classifies coal resources into three classifications of inferred, indicated and measured resources based on the distance to the information points SNI (1998).

\section{RESULTS AND DISCUSSION}

The data collected in this study consisted of collar data obtained from recording drill geometry information such as coordinate information, elevation, depth, azimuth and drill angle. Then the lithological data obtained from the descriptions of cutting or core samples from exploration drilling activities are also reconciled with logging geophysical data. Coal quality data is also obtained by analyzing the proximate and ultimate values in the laboratory for each coal sample taken. Collecting data on collars, lithology and coal quality was carried out at 32 drill point locations focused on coal and non-coal information (Figure 3).

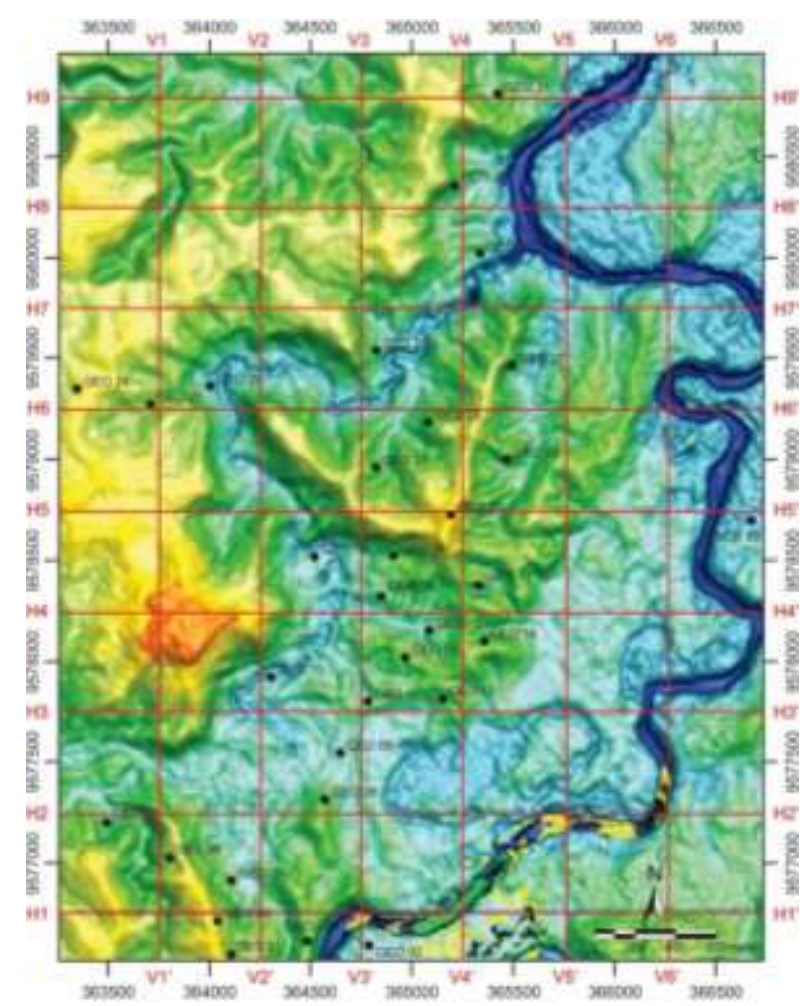

Figure 3. Drillhole and section location map as the location of collecting and analysis data.

In the study area, there are four main seams that are sorted based on the youngest to the oldest seam, namely seam A, seam B, seam C, and Seam D. Seam A is found to be the shallower at a depth of 42.00 meters while the deepest it was found at a depth of 277.30 meters with variations in the thickness of the A seam coal seam starting from 0.50 meters to 1.10 meters. Megascopically, the A seam coal layer has the physical characteristics of black color, black streak, the luster is dull dominated, cubical fraction, rather hard (Figure 4). Seam A has a roof and floor character in the form of sandy coal. 


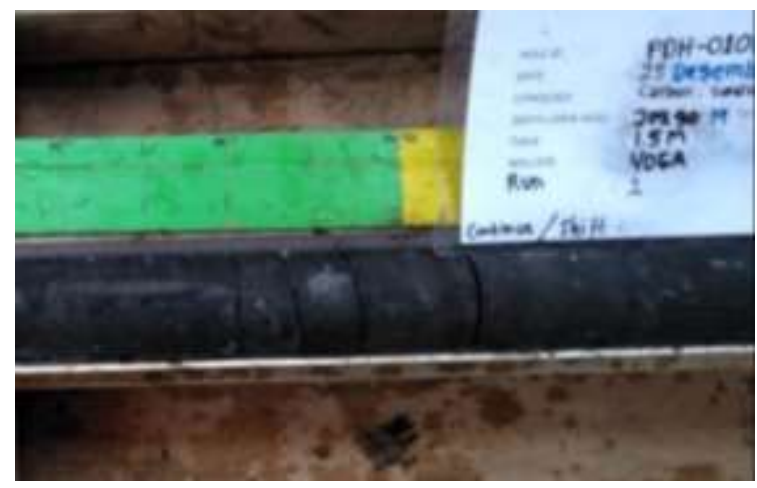

Figure 4. Characteristic of seam A.

The interburden between seam A and seam $B$ is medium sandstones with characteristics of a light gray color, has a medium sand grain size, degree of roundedsub angular rounding, well sorted sortation, contains silica (Figure 5).

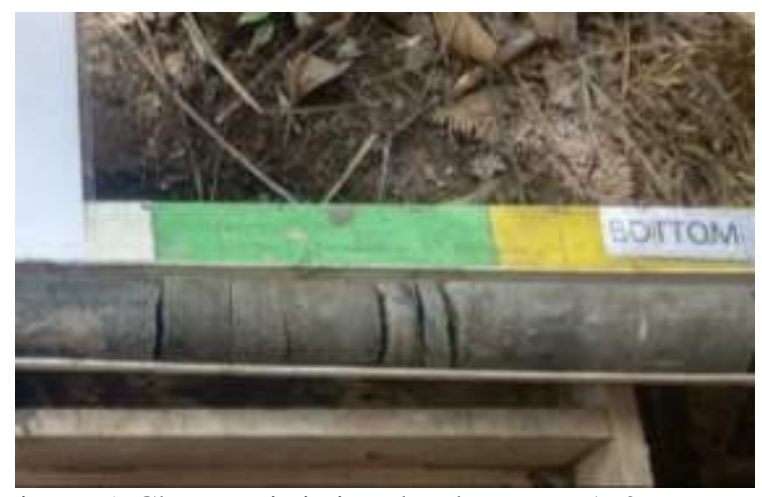

Figure 5. Characteristic interburden seam A \& B.

Seam B was found to be the shallowest at a depth of 45.70 meters, while the deepest was found at a depth of 291.90 meters with variations in the thickness starting from 5.00 meters to 12.80 meters. Megascopically, the B seam has physical characteristics of black color, black streak, bright luster, irregular fractions, and slightly hard hardness (Figure 6). Seam B has the character of a roof in the form of sandy coal and the floor in the form of muddy coal. In the southern part, seam B has branched into seam B1 and B2.

The interburden between seam B and seam $\mathrm{C}$ is in the form of claystone with a characteristic dark gray color with clay grain size, degree of rounded rolling, The interburden between seam B and seam C is in the form of claystone with a characteristic dark gray color with clay grain size, degree of rounded rolling, degree of sorting is well sorted, containing silica (Figure 7).

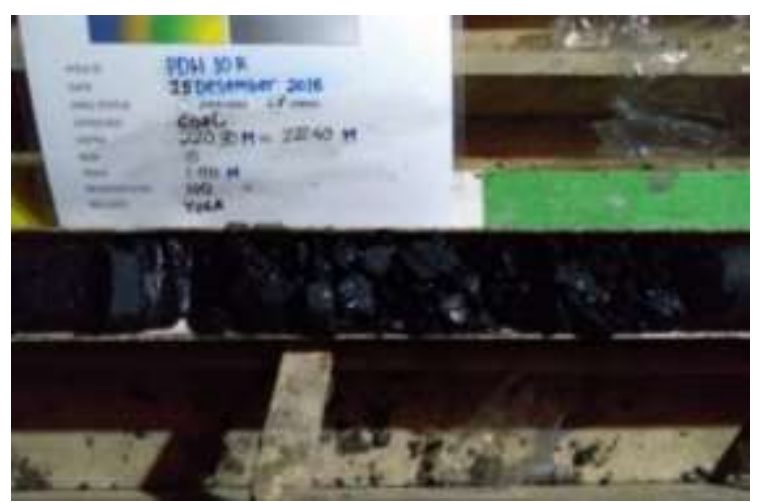

Figure 6. Characteristic of seam B.

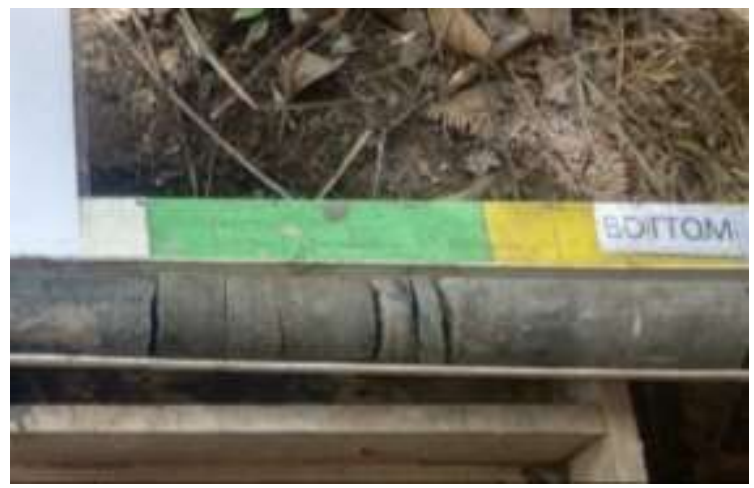

Figure 7. Characteristic interburden seam B \& C

Seam C was found to be the shallowest at a depth of 58.40 meters while the deepest was found at a depth of 308.80 meters with variations in the thickness of the $\mathrm{C}$ seam coal seam starting from 4.60 meters to 8.40 meters. Megascopically, the $\mathrm{C}$ seam coal layer has a brownish black color, brownish black streak, a dull luster, irregular fractions, slightly hard hardness (Figure 8). Seam $\mathrm{C}$ has the character of a roof in the form of muddy coal and the floor in the form of sandy coal.

The interburden between seam $\mathrm{C}$ and seam $\mathrm{D}$ is in the form of fine sandstones with a characteristic light gray color with fine sand grain size, degree of sub-rounded rounding, 
well sorted sortation, containing silica (Figure 9). Seam D was found to be the shallower at a depth of 180.60 meters while the deepest was found at a depth of 292.80 meters with variations in the thickness of the $\mathrm{D}$ seam coal seam starting from 0.50 meters to 0.70 meters. Megascopically, the D seam coal seam has the physical characteristics of black color, black scratch, dull dominated luster, cubical fraction, slightly hard hardness (Figure 10). Seam D has a roof and floor character in the form of sandy coal.

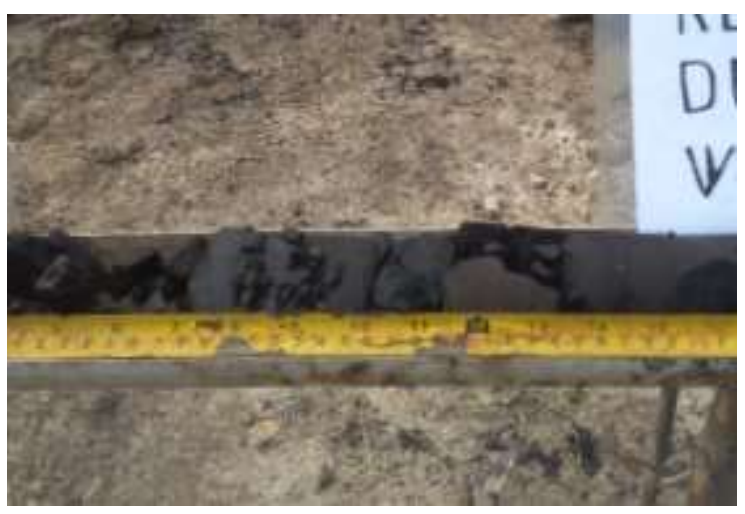

Figure 8. Characteristic of seam C.

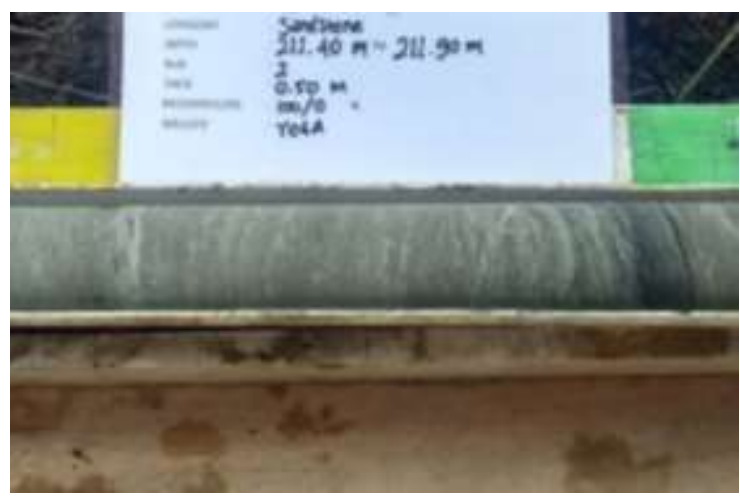

Figure 9. Characteristic interburden seam C \& D.

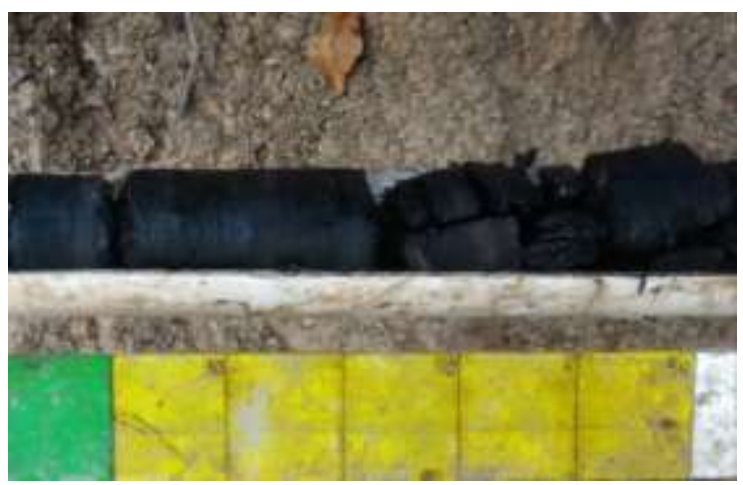

Figure 10. Characteristic of seam D.
Based on the explanation of the characteristics of each coal seam and also the interburden, the stratigraphic seam can be modeled at the research location from the youngest to the oldest, namely coal seam A, interburden seam A and seam B in the form of medium sandstones, seam B1 coal, interburden seam B1 and seam B2 are fine sandstones, seam B2 coal, interburden seam $\mathrm{B}$ and seam $\mathrm{C}$ are claystone, $\mathrm{C}$ seam coal, $\mathrm{C}$ interburden seam $\mathrm{C}$ and $\mathrm{D}$ seam, and D seam coal (Figure 11).

The continuity of the coal seam, whether seam A, seam B, seam C or seam D is generally continuous from the northern end to the southern end of the study area, although in some locations the coal seam is discontinuous because it is controlled by fluvial process and structural process (Figure 12 and 13). Based on observations of coal seam geometry models, the shape of the coal seam in the study area is included in the form of horseback, fault and also fold (Sukandarrumidi, 1995) (Figure 14 and 15).

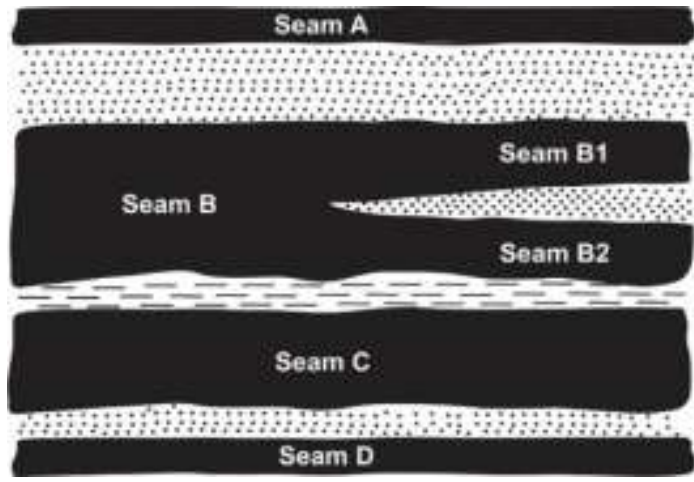

Figure 11. Coal stratigraphic model in study area.

The calculation of coal resource estimation using the circular method results in the estimated value of coal resources in the study area calculated from seam A, seam B, and seam $C$, and seam D are $74677959 \mathrm{~m}^{3}$ or 104549142 tonnes (inferred), $69043012 \mathrm{~m}^{3}$ or 96660216 tonnes (indicated), and 68041837 $\mathrm{m}^{3}$ or 95258571 tonnes (measured) (Table 1). 


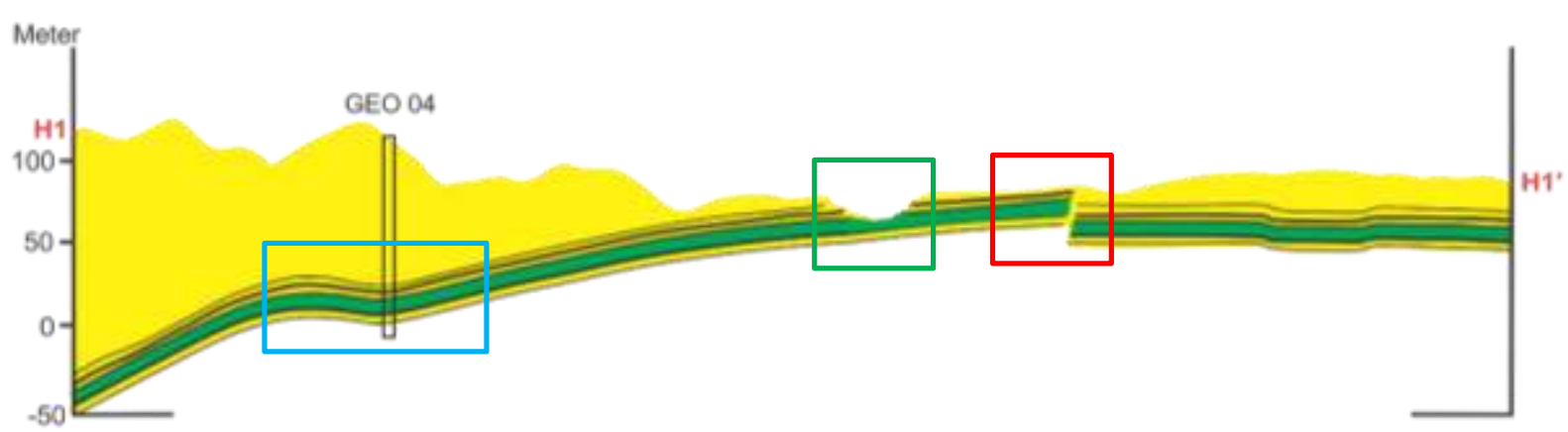

Figure 12. Section H1-H1' showing fold (blue), fault (red), and fluvial process (green).

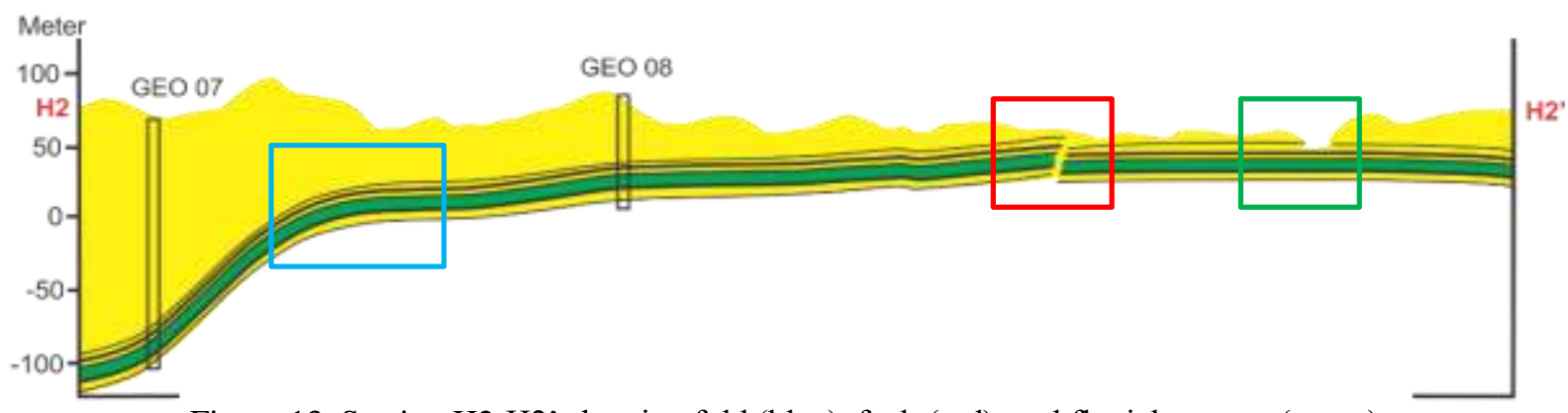

Figure 13. Section H2-H2' showing fold (blue), fault (red), and fluvial process (green).

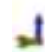

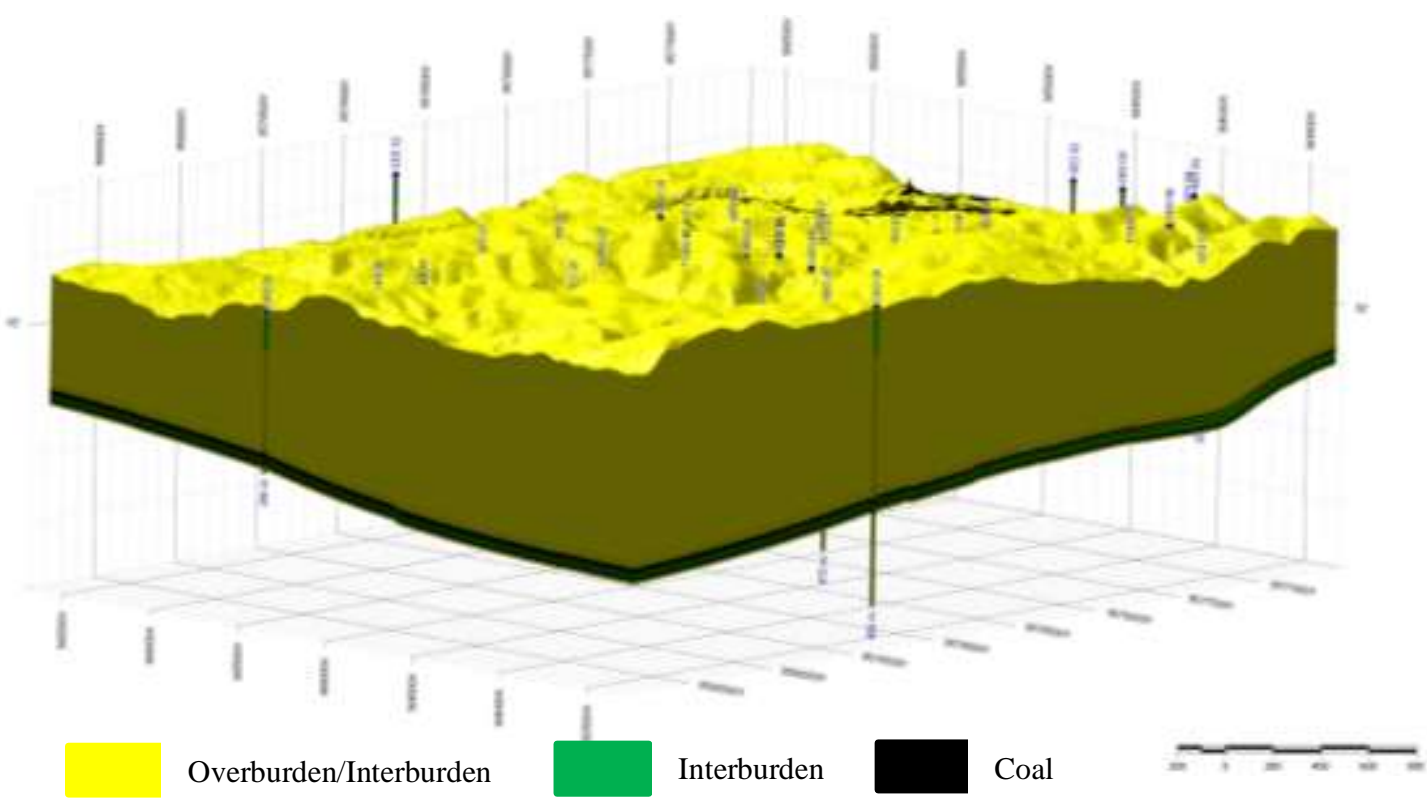

Figure 14. 3D block model showing geometry of coal seam including interburden and overburden. 


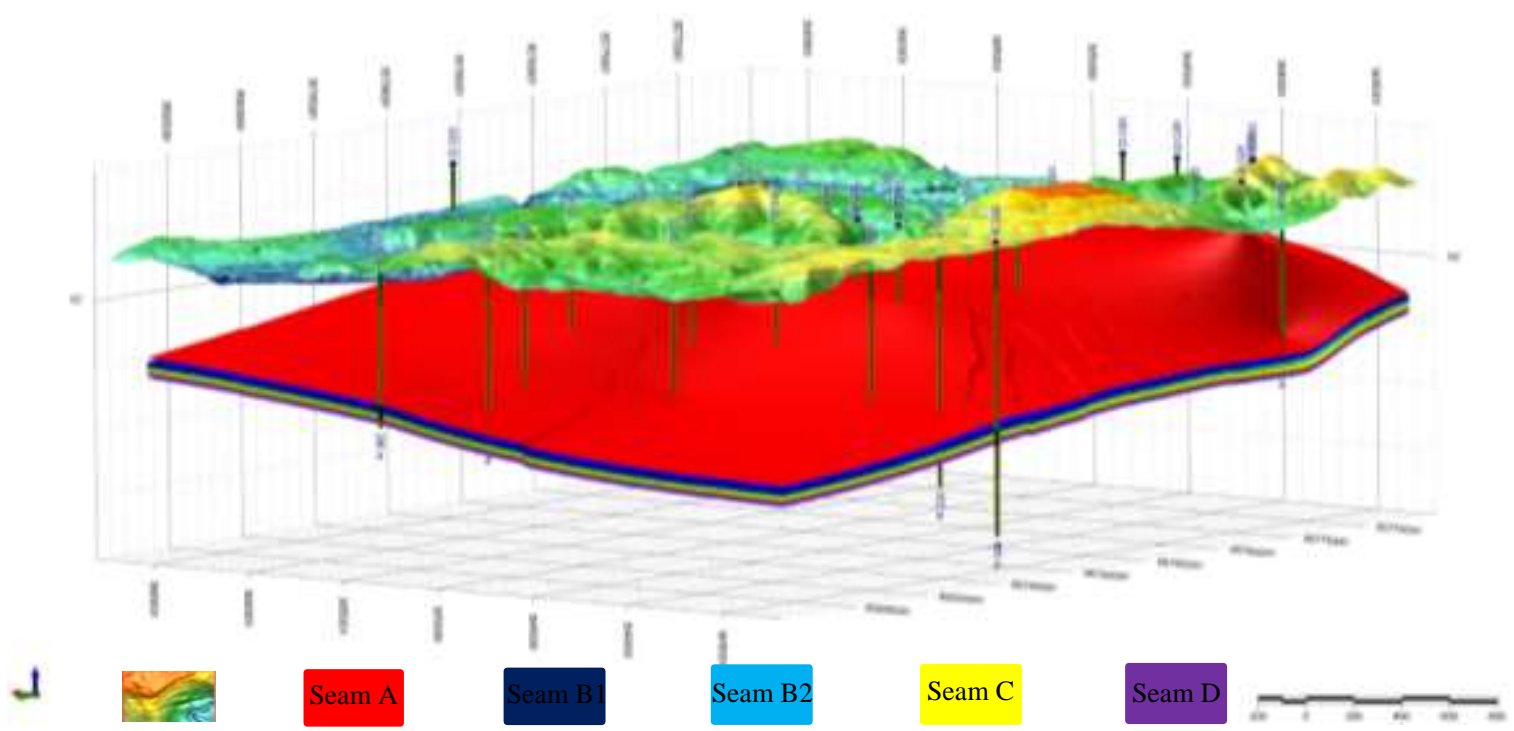

Figure 15. 3D block model showing geometry of coal seam without interburden and overburden.

Table 1. Coal resources estimation in the study area.

\begin{tabular}{crrrrrr}
\hline \multirow{2}{*}{ Seam } & \multicolumn{2}{c}{ Inferred Resources } & \multicolumn{2}{c}{ Indicated Resources } & \multicolumn{2}{c}{ Measured Resources } \\
& \multicolumn{1}{c}{$\mathbf{( m}^{\mathbf{3}} \mathbf{( \mathbf { m } ^ { 3 } )}$} & \multicolumn{1}{c}{ Ton } & \multicolumn{1}{c}{$\mathbf{( \mathbf { m } ^ { \mathbf { 3 } } )}$} & \multicolumn{1}{c}{ Ton } & \multicolumn{1}{c}{ Ton } \\
\hline A & 3080879 & 4313231 & 2972260 & 4161164 & 3186264 & 4460769 \\
B1 & 22534054 & 31547675 & 22012246 & 30817145 & 21968676 & 30756147 \\
B2 & 18417377 & 25784328 & 17789772 & 24905681 & 17809525 & 24933336 \\
C & 28475879 & 39866231 & 25238920 & 35334488 & 24575621 & 34405870 \\
D & 2169770 & 3037678 & 1029814 & 1441740 & 501751 & 702452 \\
Total & 74677959 & 104549142 & 69043012 & 96660216 & 68041837 & 95258571 \\
\hline
\end{tabular}

\section{CONCLUSION}

Coal resource estimation using the circular method results 104549142 tonnes (inferred), 96660216 tonnes (indicated), or 95258571 tonnes (measured).

\section{REFERENCES}

Barber, A. J., Crow, M. J. \& Milsom, J. S., (2005) Sumatra: Geology, Resources and Tectonic Evolution, London: Geological Society.

Badan Standarisasi Nasional Indonesia. (1998) Pedoman Pelaporan Sumberdaya dan Cadangan Batubara. Jakarta.

Bryanco, B., Yulhendra, D. and Octova, A., (2018) "Estimasi Sumberdaya Batubara Menggunakan
Metode Penampang dan Geostatistik Pada Area Timur Site Sungai Cukai, Kec. Kintap, Kab. Tanah Laut, Kalimantan Selatan”, Jurnal Bina Tambang.

Cressendo, H. and Gusman, M., (2020) "Pemodelan dan Perhitungan Estimasi Volume Akuifer Dengan Menggunakan Metode Indikator Krigging di Kecamatan Koto Tengah dan Pauh Kota, Sumatera Barat". Jurnal Bina Tambang.

Prasongko, B. K., (2000) "Geometri Lapisan Batubara", Proseding Seminar Tambang UPN, Yogyakarta.

Sukandarrumidi, (1995) Batubara dan Gambut, Universitas Gajah Mada, Yogyakarta..

USGS, (1983), "Coal Resourse Classification System of The United State Burau of Mines and United State Geological Survey", Bulletin 1450B. 